Article

\title{
Effect of Chitosan/Nano-Titanium Dioxide/Thymol and Tween Films on Ready-to-Eat Cantaloupe Fruit Quality
}

\author{
Guohua Qiao ${ }^{1}$, Zhigang Xiao ${ }^{1, *}$, Wenxin Ding ${ }^{1}$ and Ahmed Rok ${ }^{2}$ \\ 1 College of Grain Science and Technology, Shenyang Normal University, Shenyang 110034, China; \\ qiaoguohua_joe@synu.edu.cn (G.Q.); jyq5003cn@synu.edu.cn (W.D.) \\ 2 College of Science, Taif University, Taif 888, Kingdom of Saudi Arabia; rokayya.d@tu.edu.sa \\ * Correspondence: xiaozhigang_peter@synu.edu.cn; Tel.: +86-24-86505236; Fax: +86-24-86506860
}

Received: 29 October 2019; Accepted: 28 November 2019; Published: 5 December 2019

\begin{abstract}
The effect of chitosan/nano-titanium dioxide coating with antimicrobial agents on ready to eat cantaloupe fruit by chilling was investigated. In comparison with uncoated samples, ascorbic acid and juice leakage in chitosan/nano-titanium dioxide $\left(\mathrm{CH} / \mathrm{TiO}_{2}\right)$ treated fruit were significantly maintained. Likewise, the decrease of malondialdehyde (MDA) and total soluble solids (TSS) in chitosan/nano-titanium dioxide/thymol/tween $\left(\mathrm{CH} / \mathrm{TiO}_{2} / \mathrm{TT}\right)$ coated fruits was also inhibited. Total mold and yeast population counts decreased from 2.60 to $1.60 \log \mathrm{CFU} / \mathrm{g}$, respectively. Moreover, activities of water (AW) and polyphenol oxidase (PPO) were also much lower than those in control sample fruit. The results indicated that $\left(\mathrm{CH} / \mathrm{TiO}_{2} / \mathrm{TT}\right)$ coating was effective in enhancing the shelf life with acceptable in the internal and the external cantaloupe fruit quality.
\end{abstract}

Keywords: nanoparticles; shelf life; quality; ready to eat cantaloupe; chitosan

\section{Introduction}

Ready-to-eat-fruit and vegetable productions become vital as consumers are more and more conscious of healthy food intake. Therefore, ready-to-eat cut fruit is an alternate to the whole fruit consumption [1]. In general, melons are extremely difficult for direct preparation and consumption before eating that makes them convenient to be processed as ready-to eat fruit [2,3]. Also, process operations as washing, dehydration and packaging may cause some alterations, resulting in a series changes associated with microbic susceptibility, physicochemical and sensorial stability, that decrease shelf life and overall quality [4]. Cantaloupe is consumed worldwide [5-8] with its strong flavor, aroma [9]; such as Ritanol, $\beta$-carotene vitamin B complex and C; potassium, calcium and iron [10]. Studies on shelf life improvement are in depth with the packaging application such as modified atmosphere [11], irradiation, UV light and ozone [12], edible coatings and films [13]. The advance of edible coatings to extend the shelf life of ready-to eat fruit has been investigated [14]. Any material used for wrapping foods to increase their shelf life which can be eaten with or without any further removal is well known as an edible hybrid film or coating [15]. Nanotechnology has used vital metals, which currently used to reduce nutrient loss [16,17]. The physiological, chemical and transport characteristics are modified when nanoparticles are added to ordinary liquids compared to their base fluids [18,19]. Chitosan can provide films with good properties [20]. However, chitosan has weak tensile stress and enduringness once wet. It's rigid and has poor elongation properties. Nano-titanium dioxide $\left(\mathrm{TiO}_{2}\right)$ can be a photocatalyst and wide utilized as a disinfecting and self-cleaning material for coatings in several applications with a large spectrum of microorganisms [21,22]. Nano- $\mathrm{TiO}_{2}$ is non-toxic according to the American Food and Drug Administration (AFDA) to be used in human food, 
cosmetics, drugs and food contact materials. Presently there is wide interest in the self-disinfecting property of nano- $\mathrm{TiO}_{2}$ for meeting hygienic design needs [23]. The present study focused on the effects of chitosan/nano-titanium dioxide/thymol/tween films on the microbial, physical, chemical properties and additionally the evaluation impact of these coatings factors on cantaloupe qualities.

\section{Materials and Methods}

\subsection{Materials}

The uniform cantaloupe fruits were selected in weight, color and size from an orchard of Shenyang, Liaoning province, China. Chitosan with $85 \%$, glacial acetic acid $98 \%$, thymol and tween- 80 were from Sigma, St. Louis, MO, USA. Nano-TiO 2 (Particle size: $15 \mathrm{~nm}$ ) was supplied from New Material Co. (Tangshan, China).

\subsection{Chitosan/Nano-Titanium Dioxide Film Preparation}

Chitosan $(85 \%)$ was dissolved in glacial acetic acid (1\%) and stirred for $8 \mathrm{~h}$ at $300 \mathrm{rpm}$. Nano-TiO (1\%) was added and sonicated (KQ-250E, Kunshan Ultrasonic Instrument Co., Shanghai, China) under $300 \mathrm{~W}$ at $60{ }^{\circ} \mathrm{C}$ for $30 \mathrm{~min}$. Thymol and tween- 80 were added at a ratio of $0.5 \%$ and $0.25 \%$, respectively. The mixed solution was homogenized by a coarse homogenizer for $30 \mathrm{~min}$ to be sufficiently uniformly dispersed.

\subsection{Treatment and Storage}

The cutting utensils and cantaloupes were washed with running water. The fruit were cut into regular pieces with a $3 \mathrm{~cm}$ diameter [24]. The spherical cantaloupe pieces were coated using different coatings solutions for $2 \mathrm{~min}$. Four different treatments were used as: (1) Uncoated (deionized water); (2) chitosan $(\mathrm{CH})(85 \%, w / v) ;(3)$ chitosan/nano-titanium dioxide $\left(\mathrm{CH} / \mathrm{TiO}_{2}\right)(1 \%, w / v)$ and $(4)$ chitosan/nano-titanium dioxide/thymol/tween $\left(\mathrm{CH} / \mathrm{TiO}_{2} / \mathrm{TT}\right)(1 \%, w / v)$. The fruits were dripped for 1 $\mathrm{min}$, placed on a trellis shelf and dried at room temperature $\left(25^{\circ} \mathrm{C}\right)$. Approximately $250 \mathrm{~g}$ of coated cantaloupe pieces was packed into $40 \mathrm{~mm}$ thickness polypropylene bag and sealed. Samples were chilled and conducted every 2 days. Microbiological analysis (mold and yeast population counts), physical analysis (juice leakage and color) and chemical analysis ( $\mathrm{pH}$, titratable acidity, total soluble solids, ascorbic acid and malondialdehyde) were detected. Besides phenolic enzymes (polyphenol oxidase and peroxidase) and water activities were measured.

\subsection{Microbiological Analysis}

Microbiological analyses were performed by evaluating total mold and yeast population counts [25]. Sample (25 g) was homogenized with $(0.1 \%)$ sterile peptone water for $2 \mathrm{~min}$ in a ratio of.1:10 (sample: peptone water, $w / v)$ using a lab blender (FP190 Series, Kenwood, Shenzhen, China) under sterile conditions as Rose Bengal Medium (RBM) for total mold and yeast population counts which incubated for $5 \mathrm{~d}$ at $\left(28^{\circ} \mathrm{C}\right)$. The results were expressed in $(\log \mathrm{CFU} / \mathrm{g})$.

Juice leakage was examined every two days during until the end of each storage time. Surface color was evaluated by using a ZE-6000 Color Difference Meter (Nippon Denshoku, Kogyo Co., Tokyo, Japan). Values of $L^{*}$. (lightness), $a^{*}$ (green-red chromaticity) and $b^{*}$ (blue-yellow chromaticity) were recorded [26].

\section{5. pH, Titratable Acidity, Total Soluble Solids, Ascorbic Acid and Malondialdehyde Measurements}

Cantaloupe pieces were blended using a blender (FP190 Series, Kenwood, Shanghai, China) and the $\mathrm{pH}$ of the juice was measured using a digital $\mathrm{pH}$ meter (pH Electrode Probe BNC, Arduino, Shanghai, China) according to the Official Methods of Analysis (AOAC) 981.12 [27]. Titratable acidity (TAA) was determined using the titration method according to AOAC method 942.15 [27]. The results were expressed in \% citric acid. Total soluble solids (TSS) were measured using a digital 
refractometer (Atago Co., Tokyo, Japan) and expressed in \%. Ascorbic acid content was detected using 2, 6-dichloroindophenol titration [27]. The results were expressed as ( $\mathrm{mg} / 100 \mathrm{~g})$. A $2 \mathrm{~g}$ sample of cantaloupe pieces was homogenized with $10 \mathrm{~mL}$ of $100 \mathrm{~g} / \mathrm{L}$ trichloroacetic acid and centrifuged at $12,000 \mathrm{rpm}$ for $20 \mathrm{~min}$ to measure malondialdehyde (MDA) content. A $2 \mathrm{~mL}$ aliquot of supernatant was mixed with $2 \mathrm{~mL}$ of $0.67 \%$ thiobarbituric acid and incubated in boiling water for $15 \mathrm{~min}$, cooled quickly and then centrifuged $20 \mathrm{~min}$ at 12,000 rpm. The absorbance of the supernatant was measured at $(450,532$ and $600 \mathrm{~nm})$, respectively [28].

\subsection{Water and Phenolic Enzyme Activities Measurements}

Water activity (AW) was determined by using a water activity meter (Decagon Devices, Pullman, WA, USA). The peroxidase (POD) reaction solution $(2 \mathrm{~mL})$ contained $20 \mathrm{mM}$ phosphate buffer $(\mathrm{pH} 6.5)$, $20 \mathrm{Mm}$ guaiacol, $40 \mathrm{mM} \mathrm{H}_{2} \mathrm{O}_{2}$, and $0.1 \mathrm{~mL}$ enzyme extract. The reaction solution absorbance was determined every $40 \mathrm{~s}$ at $470 \mathrm{~nm}$. POD activity was calculated as an adjustment of 0.01 in absorbance/minute [29]. Cantaloupe tissues (4 g) were homogenized with $0.1 \mathrm{M} \mathrm{Na}_{2} \mathrm{HPO}_{4}-\mathrm{NaH}_{2} \mathrm{PO}_{4}$ buffer ( $\mathrm{pH} 6.5$ ) containing $2 \%$ insoluble polyvinyl pyrrolidone for measuring polyphenol oxidase (PPO) activity. PPO activity was examined with catechol as a substrate. The enzyme solution $(0.2 \mathrm{~mL})$ was added to $(2.8 \mathrm{~mL})$ of $10 \mathrm{mM}$ catechol in $0.01 \mathrm{M}$ sodium phosphate buffer ( $\mathrm{pH}$ 6.5). PPO activity was calculated as the amount of enzyme which caused an adjustment of 0.001 in the absorbance/minute at $410 \mathrm{~nm}[29]$.

\subsection{Statistical Analysis}

All measurements were analyzed using the test of the SPSS 16.0 software and the results are expressed as mean \pm standard deviation (SD). Analysis of variance (ANOVA) was used to evaluate differences between treatments. $p$-values was significantly lower than 0.05 .

\section{Results and Discussions}

\subsection{Microbiological Analysis}

Figure 1 shows the total mold and yeast population counts of coated cantaloupe samples with or without nano-treatment. The microbial population growth was comparable for total mold and yeast population counts [30]. The high sugar and $\mathrm{pH}$ contents can promote microbial growth [31]. The uncoated samples reached the highest microbial limit earliest during the whole storage which was 8 days. When coatings combined with $\mathrm{TiO}_{2}$, all coated samples had lower fungal growth compared to the control. The reduction of fungal growth in coated samples can be due to the chitosan combination with nano-material [32,33].

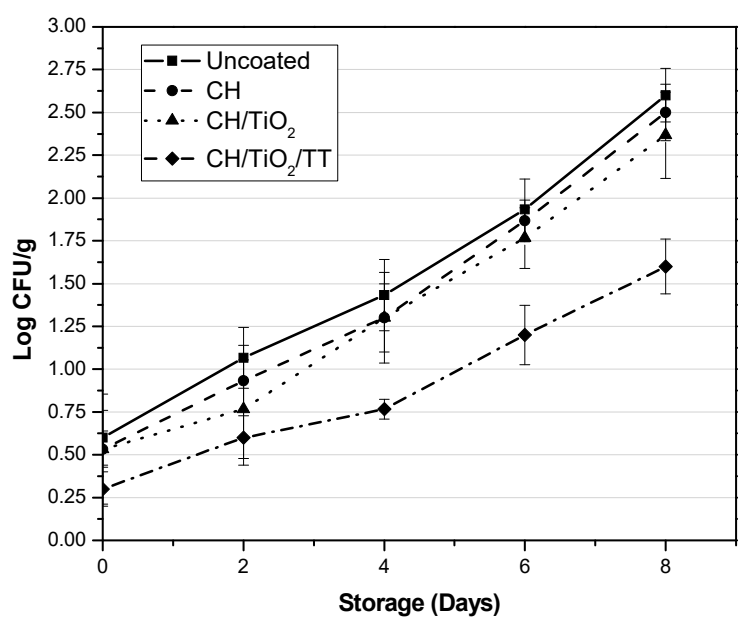

Figure 1. Effects of coating treatments total mold and yeast population count of cantaloupe fruit. 
$\mathrm{CH} / \mathrm{TiO}_{2} / \mathrm{TT}$ maintained the lowest total mold and yeast population count until the end of storage period. It is well-known that chitosan combination with nano-material has antimicrobial activity due to electronegative and polycationic on the surface of the cells that lead to cell permeability modification. Consequently, these results in leakage of proteinaceous constituents and intracellular electrolytes [33].

\subsection{Juice Leakage and Color}

Juice leakage increased in the samples during storage was observed in all treatments due to transpiration and respiration. As shown in Table 1, the films could diminish the increase in the juice leakage, while the juice leakage of the uncoated samples was the highest. On the 8th day, the juice leakage of cantaloupe treated with the $\mathrm{CH} / \mathrm{TiO}_{2}$ film was $0.93 \%$ lower than the other treatments. It was apparent that the treatment of cantaloupe with a $\mathrm{CH} / \mathrm{TiO}_{2}$ film could inhibit juice leakage and can maintain fruit weight in chilled storage. The same results were also proved which performed semi-films and prevent juice leakage [9].

Table 1. Effect of coating treatments on juice leakage.

\begin{tabular}{ccccc}
\hline \multirow{2}{*}{ Storage (Days) } & \multicolumn{4}{c}{ Juice Leakage (\%) } \\
\cline { 2 - 5 } & Uncoated & $\mathbf{C H}$ & $\mathbf{C H} / \mathbf{T i O}_{\mathbf{2}}$ & $\mathbf{C H} / \mathbf{T i O}_{2} / \mathbf{T T}$ \\
\hline 0 & $0.0 \pm 0.00^{\mathrm{b}}$ & $0.0 \pm 0.00^{\mathrm{a}}$ & $0.0 \pm 0.00^{\mathrm{b}}$ & $0.0 \pm 0.00^{\mathrm{a}}$ \\
2 & $2.29 \pm 1.59^{\mathrm{ab}}$ & $2.16 \pm 2.17^{\mathrm{a}}$ & $1.92 \pm 2.40^{\mathrm{ab}}$ & $1.85 \pm 2.14^{\mathrm{a}}$ \\
4 & $3.29 \pm 1.61^{\mathrm{ab}}$ & $2.26 \pm 1.89^{\mathrm{a}}$ & $2.68 \pm 0.29^{\mathrm{a}}$ & $2.68 \pm 2.57^{\mathrm{a}}$ \\
6 & $6.33 \pm 4.51^{\mathrm{a}}$ & $2.12 \pm 1.96^{\mathrm{a}}$ & $1.57 \pm 0.31^{\mathrm{ab}}$ & $2.43 \pm 1.39^{\mathrm{a}}$ \\
8 & $4.78 \pm 3.21^{\mathrm{ab}}$ & $1.54 \pm 0.80^{\mathrm{a}}$ & $0.93 \pm 0.14^{\mathrm{ab}}$ & $1.92 \pm 1.21^{\mathrm{a}}$ \\
\hline
\end{tabular}

Note: Means which do not have a common letter $(\mathrm{a}, \mathrm{b}, \mathrm{c}, \mathrm{d})$ are significantly different $(p \leq 0.05)$. Vertical bars represent $\pm \mathrm{SD}$. The values in parentheses indicate \pm standard deviation. $\mathrm{CH}=$ chitosan, $\mathrm{CH} / \mathrm{TiO}_{2}=$ chitosan/nano-titanium dioxide, and $\mathrm{CH} / \mathrm{TiO}_{2} / \mathrm{TT}=$ chitosan/nano-titanium dioxide/thymol/tween.

Lightness $\left(L^{*}\right)$ values ranged from 26 to 38 on day 0. Though a little particular trend was established of fruit lightness, $\mathrm{CH} / \mathrm{TiO}_{2} / \mathrm{TT}$ samples remained lighter (Figure 2a). Uncoated and $\mathrm{CH}$ samples showed more signs of darkening. $\mathrm{CH} / \mathrm{TiO}_{2}$ treatment affected $(p>0.05)$ the redness degree ( $a^{*}$ values) in a comparison to the control samples (Figure $2 b$ ). The value of $b^{*}$ for uncoated samples is significantly higher than that of $\mathrm{CH} / \mathrm{TiO}_{2} / \mathrm{TT}$ at days 4,6 and 8 (Figure 2c). This result recommends that nano-coating preserved the yellowness to a certain grade. The same results for color determination have been estimated for $\mathrm{CH}$ and control samples [34].

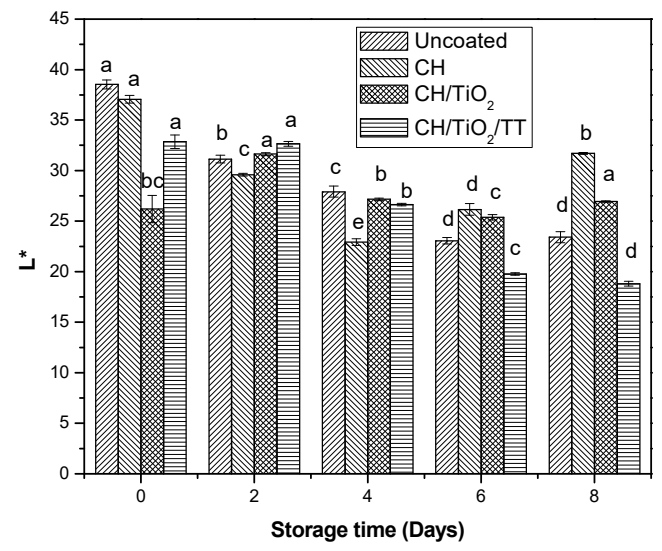

(a)

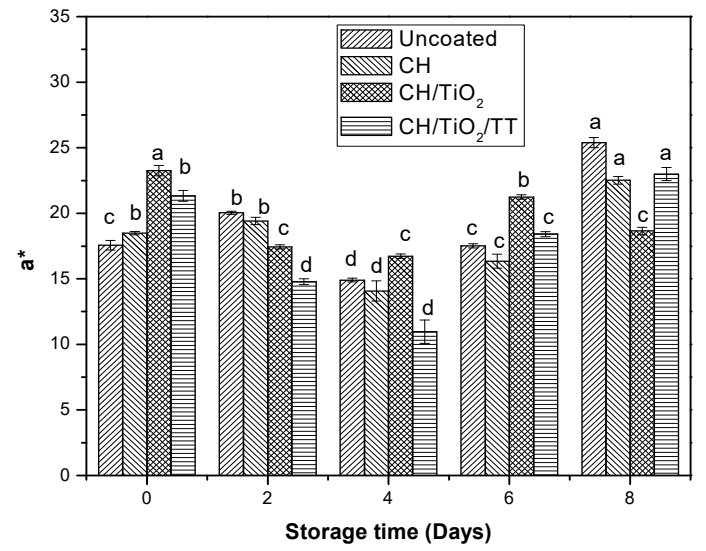

(b)

Figure 2. Cont. 


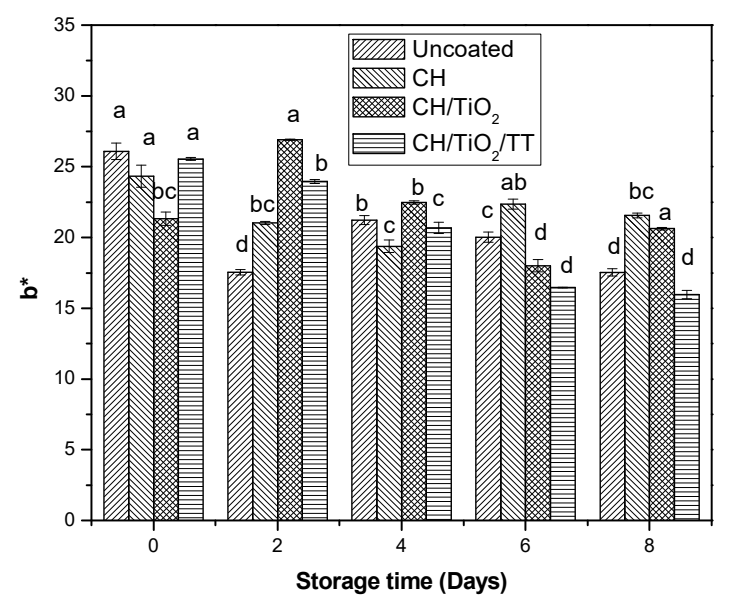

(c)

Figure 2. Means which do not have a common letter $(a, b, c, d)$ are significantly different $(p \leq 0.05)$. Vertical bars represent $\pm \mathrm{SD}$. (a) $L^{*},(\mathbf{b}) a^{*}$ and (c) $b^{*}$ values of cantaloupe during storage.

\subsection{Chemical Analysis}

Initial ranges of $\mathrm{pH}$ and TAA of ready-to eat cantaloupes were $5.18 \%-5.95 \%$ and $0.09 \%-0.18 \%$ citric acid, respectively. Based on Table 2, the decrease in $\mathrm{pH}$ for uncoated ready-to eat cantaloupes was sooner than that treated with $\mathrm{CH}$ as observed on 8th day. The decrease in $\mathrm{pH}$ and acidity increase during storage of ready-to eat cantaloupes correlated well with the microbial growth population. Uncoated cantaloupes which had high microbial growth demonstrated a faster rate of $\mathrm{pH}$ decrease and acidity increase during the storage time. On 8th day, the TAA values of all the coated cantaloupes were higher $(p \leq 0.05)$ though $\mathrm{CH}$ and nano- $\mathrm{TiO}_{2} / \mathrm{TT}$ in the different coating treatments. The TAA of ready-to eat cantaloupes generally corresponded to the examined $\mathrm{pH}$ of cantaloupe multi layers edible coatings [6].

Initial TSS of ready-to eat cantaloupes were $9.56^{\circ}$ Brix (Table 2). TSS of ready-to eat cantaloupes remained constant during the storage between all treatments except $\mathrm{CH} / \mathrm{TiO}_{2} / \mathrm{TT}$. TSS content increased after the 2nd day of storage may be due to ripening and loss of water, but slightly then decreased during due to the respiration $[35,36]$. The chilling resulted in low respiration and insignificant changes in TSS [37].

Analogously, the results in Table 2 revealed a significant decline in ascorbic acid value of uncoated cantaloupe alongside the storage time. Though, the decrease rate in ascorbic acid content was slower in $\mathrm{CH} / \mathrm{TiO}_{2} / \mathrm{TT}$ sample compared with other treated samples. The initial ascorbic acid content of cantaloupe fruit was $22.19 \mathrm{mg} / 100 \mathrm{~g}$. On 8th day, ascorbic acid contents of cantaloupe fruits treated with $\mathrm{CH}$ coating and $\mathrm{CH} / \mathrm{TiO}_{2} / \mathrm{TT}$ film were maintained in the levels of 22.18 and $22.15 \mathrm{mg} / 100 \mathrm{~g}$, respectively, on the other side $\mathrm{CH} / \mathrm{TiO}_{2}$ sample was $22.46 \mathrm{mg} / 100 \mathrm{~g}$. $\mathrm{CH} / \mathrm{TiO}_{2}$ combination was much more effective in increasing the content of ascorbic acid. Date was also identified in cantaloupe preservation using the film of chitosan and nano-silica [6].

MDA could specify the degree of the cytoplasmic membrane oxidation. As shown in Table 2, MDA content of $\mathrm{CH} / \mathrm{TiO}_{2} / \mathrm{TT}$ coating $(0.12 \mathrm{nmol} / \mathrm{g})$ was lower than the uncoated samples $(1.80 \mathrm{nmol} / \mathrm{g}$; $p<0.05$ ) on day 8. Cantaloupes treated with nano- $\mathrm{TiO}_{2}$ coating delayed the MDA increase, due to the higher POD activity (Figure 3a). Similar research proved that the MDA content was the lowest [38]. 
Table 2. Coating treatments on chemical analysis.

\begin{tabular}{|c|c|c|c|c|}
\hline \multirow{2}{*}{ Storage (Days) } & Uncoated & $\mathrm{CH}$ & $\mathrm{CH} / \mathrm{TiO}_{2}$ & $\mathrm{CH} / \mathrm{TiO}_{2} / \mathrm{TT}$ \\
\hline & \multicolumn{4}{|c|}{$\mathrm{pH}$} \\
\hline 0 & $5.70 \pm 0.07 b c$ & $5.95 \pm 0.04^{a}$ & $5.78 \pm 0.10^{\mathrm{a}}$ & $5.82 \pm 0.01^{\mathrm{a}}$ \\
\hline 2 & $5.83 \pm 0.01^{\mathrm{a}}$ & $5.81 \pm 0.06^{\mathrm{a}}$ & $5.59 \pm 0.22 \mathrm{ab}$ & $5.52 \pm 0.10^{b}$ \\
\hline 4 & $5.77 \pm 0.07^{c}$ & $5.43 \pm 0.14^{b}$ & $5.59 \pm 0.04^{a b}$ & $5.34 \pm 0.02^{c}$ \\
\hline 6 & $5.67 \pm 0.03^{a b}$ & $5.32 \pm 0.09 b c$ & $5.38 \pm 0.03 \mathrm{bc}$ & $5.34 \pm 0.10^{c}$ \\
\hline \multirow[t]{2}{*}{8} & $5.51 \pm 0.01^{\mathrm{d}}$ & $5.19 \pm 0.07^{\mathrm{c}}$ & $5.18 \pm 0.04^{c}$ & $5.21 \pm 0.08^{c}$ \\
\hline & \multicolumn{4}{|c|}{ TAA (Citric Acid, \%) } \\
\hline 0 & $0.09 \pm 0.00^{a b}$ & $0.09 \pm 0.00 \mathrm{bc}$ & $0.09 \pm 0.00^{b}$ & $0.09 \pm 0.00^{c}$ \\
\hline 2 & $0.09 \pm 0.01^{\mathrm{ab}}$ & $0.10 \pm 0.01^{b}$ & $0.10 \pm 0.01^{b}$ & $0.14 \pm 0.02^{b}$ \\
\hline 4 & $0.08 \pm 0.01^{b}$ & $0.09 \pm 0.01 \mathrm{bc}$ & $0.10 \pm 0.01^{b}$ & $0.09 \pm 0.01^{\mathrm{c}}$ \\
\hline 6 & $0.07 \pm 0.02^{b}$ & $0.08 \pm 0.00^{c}$ & $0.08 \pm 0.01^{b}$ & $0.11 \pm 0.01^{\mathrm{c}}$ \\
\hline \multirow[t]{2}{*}{8} & $0.12 \pm 0.03^{\mathrm{a}}$ & $0.14 \pm 0.01^{\mathrm{a}}$ & $0.17 \pm 0.02^{\mathrm{a}}$ & $0.18 \pm 0.02^{\mathrm{a}}$ \\
\hline & \multicolumn{4}{|c|}{ TSS $\left({ }^{\circ}\right.$ Brix $)$} \\
\hline 0 & $9.56 \pm 0.07^{a}$ & $9.56 \pm 0.07^{a}$ & $9.56 \pm 0.07^{\mathrm{ab}}$ & $9.56 \pm 0.07^{a}$ \\
\hline 2 & $9.70 \pm 0.06^{\mathrm{a}}$ & $9.64 \pm 0.03^{a}$ & $9.90 \pm 0.18^{a}$ & $9.33 \pm 0.03^{a}$ \\
\hline 4 & $9.42 \pm 0.25^{\mathrm{a}}$ & $9.55 \pm 0.11^{\mathrm{a}}$ & $9.74 \pm 0.44^{\mathrm{a}}$ & $8.67 \pm 0.29 b$ \\
\hline 6 & $9.30 \pm 0.14^{\mathrm{a}}$ & $9.50 \pm 0.21^{\mathrm{a}}$ & $9.29 \pm 0.13^{b}$ & $9.31 \pm 0.15^{\mathrm{a}}$ \\
\hline \multirow[t]{2}{*}{8} & $9.40 \pm 0.42^{\mathrm{a}}$ & $9.14 \pm 0.14^{b}$ & $9.29 \pm 0.12^{b}$ & $8.14 \pm 0.12^{c}$ \\
\hline & \multicolumn{4}{|c|}{ Ascorbic Acid (mg/100 g) } \\
\hline 0 & $22.19 \pm 0.70^{a}$ & $22.19 \pm 0.75^{c}$ & $22.19 \pm 0.75^{\mathrm{d}}$ & $22.19 \pm 0.75^{c}$ \\
\hline 2 & $22.64 \pm 0.31^{a}$ & $24.84 \pm 0.43^{a}$ & $24.88 \pm 0.26^{\mathrm{a}}$ & $24.41 \pm 0.33^{a}$ \\
\hline 4 & $22.02 \pm 0.30^{a}$ & $23.50 \pm 0.32^{b}$ & $23.53 \pm 0.41^{b}$ & $24.21 \pm 0.26^{a}$ \\
\hline 6 & $19.84 \pm 0.46^{b}$ & $23.15 \pm 0.03^{b}$ & $23.31 \pm 0.41 \mathrm{bc}$ & $23.31 \pm 0.22^{b}$ \\
\hline \multirow[t]{2}{*}{8} & $19.42 \pm 2.15^{a}$ & $22.18 \pm 0.18^{c}$ & $22.46 \pm 0.48^{\mathrm{cd}}$ & $22.15 \pm 0.15^{c}$ \\
\hline & \multicolumn{4}{|c|}{ MDA(nmol/g) } \\
\hline 0 & $0.51 \pm 0.06^{\mathrm{d}}$ & $0.51 \pm 0.06^{\mathrm{a}}$ & $0.51 \pm 0.06^{a}$ & $0.51 \pm 0.06^{\mathrm{a}}$ \\
\hline 2 & $0.52 \pm 0.04^{d}$ & $0.50 \pm 0.02^{a}$ & $0.47 \pm 0.02^{a b}$ & $0.46 \pm 0.04^{\mathrm{ab}}$ \\
\hline 4 & $0.91 \pm 0.13^{c}$ & $0.41 \pm 0.03^{b}$ & $0.43 \pm 0.02^{b}$ & $0.41 \pm 0.01^{b}$ \\
\hline 6 & $1.26 \pm 0.26^{b}$ & $0.35 \pm 0.05^{b}$ & $0.21 \pm 0.04^{c}$ & $0.20 \pm 0.01^{\mathrm{c}}$ \\
\hline 8 & $1.80 \pm 0.05^{a}$ & $0.22 \pm 0.02^{c}$ & $0.15 \pm 0.04^{c}$ & $0.12 \pm 0.01^{d}$ \\
\hline
\end{tabular}

Note: The values in parentheses indicate \pm standard deviation. $\mathrm{CH}=$ chitosan, $\mathrm{CH} / \mathrm{TiO}_{2}=$ chitosan/nano-titanium dioxide, and $\mathrm{CH} / \mathrm{TiO}_{2} / \mathrm{TT}$ = chitosan/nano-titanium dioxide/thymol/tween.

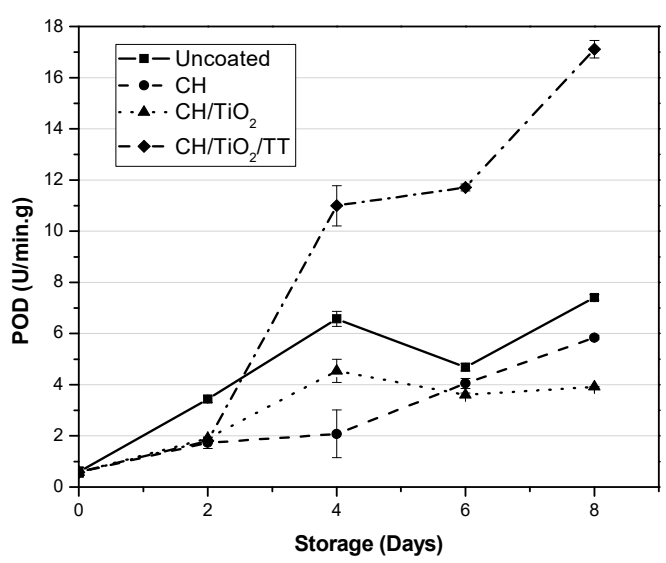

(a)

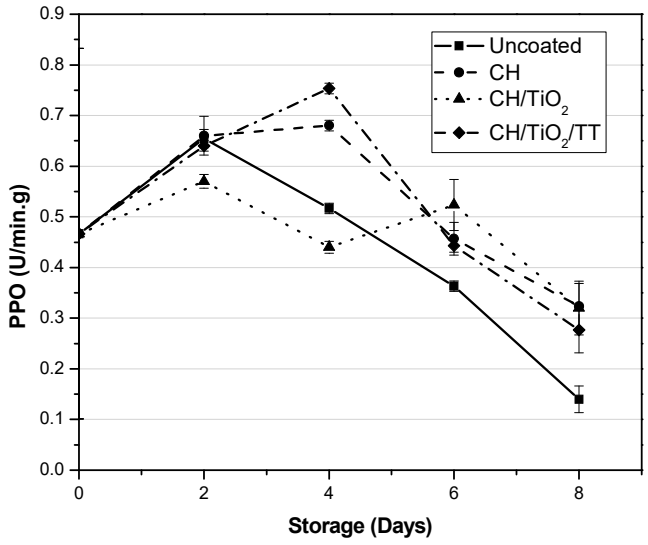

(b)

Figure 3. Cont. 


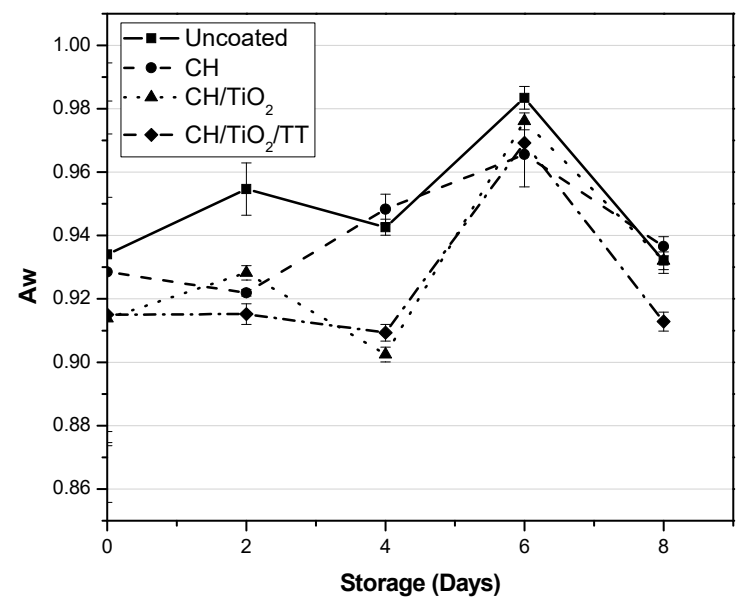

(c)

Figure 3. Effect of coating treatments on phenolic enzymes and water activity, (a) peroxidase enzyme activity, (b) polyphenol oxidase enzyme activity and (c) water activity of cantaloupe fruits.

\subsection{Phenolic Enzymes and Water Activity}

Figure 3a shows the effects of coating treatments on the POD activity of fresh-cut cantaloupes. Generally, cantaloupes had lower POD activity as compared to the other uncoated samples (day 0) regardless of treatments. This could be due to the low $\mathrm{O}_{2}$ level developed in the fruit coatings [39]; and the possible reduction of carotene which can be one of the important factors of POD activity [40]. On the other hand, $\mathrm{CH} / \mathrm{TiO}_{2} / \mathrm{TT}$ samples had higher POD activity as compared to other samples during storage.

Figure $3 \mathrm{~b}$ presents the effects of coating on PPO activity in ready-to eat cantaloupes. PPO is an enzyme which oxidizes phenolic compounds thereby producing quinones, which is then converted to brown pigments known as melanins [41]. It is known that $\mathrm{O}_{2}$ is required for PPO activity to occur. The packages of ready-to eat cantaloupes produced low $\mathrm{O}_{2}$ concentration, which could explain the reduction of PPO activity in the samples [3]. Thereafter, the PPO activity remained constant throughout the storage for samples treated with $\mathrm{CH}$ or nano- $\mathrm{TiO}_{2}$ without significant difference $(p>0.05)$. In a word, $\mathrm{CH} / \mathrm{TiO}_{2} / \mathrm{TT}$ treatment slightly influenced the PPO activity of cantaloupes. These results could be due to oxidizable phenols in cantaloupe [42]. Generally, the maintenance of POD and PPO activities in $\mathrm{CH} / \mathrm{TiO}_{2} / \mathrm{TT}$ samples indicated the presence of consistent abiotic stress in these samples during storage as compared to uncoated samples.

The AW can define as the free moisture content (MC). $\mathrm{CH} / \mathrm{TiO}_{2} / \mathrm{TT}$-treated sample had a lower AW than uncoated sample $(p<0.05)$. This result can be due to $\mathrm{CH} / \mathrm{TiO}_{2} / \mathrm{TT}$-treated samples contained antimicrobial agents, which promoted the interaction of water and sugar molecules via hydrogen bond [43].

\section{Conclusions}

Nano-titanium dioxide based on thymol, tween and their combination with chitosan coating films were effective for extending cantaloupes shelf life. The chitosan/nano-titanium dioxide/thymol/tween $\left(\mathrm{CH} / \mathrm{TiO}_{2} / \mathrm{TT}\right)$ film was the most effective at controlling mold and yeast population growth, phenol enzymes, total soluble sugar and malondialdehyde, while chitosan/nano-titanium film $\left(\mathrm{CH} / \mathrm{TiO}_{2}\right)$ had only an effect on ascorbic acid and juice leakage. Chitosan film $(\mathrm{CH})$ decreased the brightness of cantaloupe fruits during storage time.

Author Contributions: Conceptualization, G.Q. and Z.X.; methodology, G.Q., Z.X. and W.D.; software, A.R.; validation, Z.X., G.Q. and A.R.; formal analysis, A.R. and W.D.; investigation, G.Q.; resources, Z.X.; data curation, 
W.D.; writing—original draft preparation, G.Q. and A.R.; writing—review and editing, A.R.; visualization, A.R.; supervision, Z.X.; project administration, Z.X.; funding acquisition, Z.X.

Funding: This research was financially supported by College of student innovation and entrepreneurship, fund No. 201910166090 and Tibetan natural science, fund No. XZ2018ZRG-36.

Conflicts of Interest: The authors declared no conflict of interest.

\section{References}

1. Bierhals, V.S.; Chiumarelli, M.; Hubinger, M.D. Effect of cassava starch coating on quality and shelf life of fresh-cut pineapple (Ananascomosus L. Merril cv "Pérola"). J. Food Sci. 2011, 76, 62-72. [CrossRef]

2. Amaro, A.L.; Beaulieu, J.C.; Grimm, C.C.; Stein, R.E.; Almeida, D.P.F. Effect of oxygen on aroma volatiles and quality of fresh-cut cantaloupe and honeydew melons. Food Chem. 2012, 130, 49-57. [CrossRef]

3. Koh, P.C.; Noranizan, M.A.; Hanani, Z.A.N.; Karim, R.; Rosli, S.Z. Application of edible coatings and repetitive pulsed light for shelf life extension of fresh-cut cantaloupe (Cucumismelo L. reticulatus cv. Glamour). Postharvest Biol. Tech. 2017, 129, 64-78. [CrossRef]

4. Koh, P.C.; Noranizan, M.A.; Karim, R.; NurHanani, Z.A.; Rosli, S.Z.; Hambali, N.H. Enzymatic activity of alginate coated and pulsed light treated fresh-cut cantaloupes (Cucumismelo L. var. reticulatus cv. Glamour) during chilled storage. Int. Food Res. J. 2019, 26, 547-556.

5. Kasim, R.; Kasim, M.U. Biochemical and color changes of fresh-cut melon (Cucumismelo L.cv. Galia) treated with UV-C. Food Sci. Tech. 2014, 34, 547-551. [CrossRef]

6. Martiñon, M.E.; Moreira, R.G.; Castell-Perez, M.E.; Gomes, C. Development of a multilayered antimicrobial edible coating for shelflife extension of fresh-cut cantaloupe (Cucumismelo L.) stored at $4^{\circ} \mathrm{C}$. LWT Food Sci. Tech. 2014, 56, 341-350. [CrossRef]

7. Chong, J.X.; Lai, S.; Yang, H. Chitosan combined with calcium chloride impacts fresh-cut honeydew melon by stabilising nanostructures of sodium-carbonate-soluble pectin. Food Control 2015, 53, 195-205. [CrossRef]

8. Ortiz-Duarte, G.; Pérez-Cabrera, L.E.; Artés-Hernández, F.; Martínez-Hernández, G.B. Ag-chitosan nanocomposites in edible coatings affect the quality of fresh-cut melon. Postharvest Biol. Tech. 2019, 147, 174-184. [CrossRef]

9. Treviño-Garza, M.Z.; Correa-Cerón, R.C.; Ortiz-Lechuga, E.G.; Solís-Arévalo, K.K.; Castillo-Hernández, S.L.; Gallardo-Rivera, C.T.; Arévalo Niño, K. Effect of linseed (Linumusitatissimum) mucilage and chitosan edible coatings on quality and shelf-life of fresh-cut cantaloupe (Cucumismelo). Coatings 2019, 9, 368. [CrossRef]

10. Waqas, A.; Butt, M.S. Application of biodegradable coatings to improve quality and shelf life of minimally processed melon dices. Pakistan J. Food Sci. 2014, 24, 82-90.

11. Soliva-Fortuny, R.C. Polysaccharide coatings extend fresh-cut fruit shelf life. Emerg. Food Res. Dev. Report. 2010, 21, 1-2.

12. Lamiranka, O.; Kueneman, D.; Ukuku, D.; Bett-Garber, K. Effect of processing under ultraviolet light on the shelf life of fresh-cut cantaloupe melon. J. Food Sci. 2005, 70, C534-C539. [CrossRef]

13. Raybaudi-Massilia, R.M.; Mosqueda-Melgar, J.; Martin-Belloso, O. Ediblealginate-based coating as carrier of antimicrobials to improve shelf life and safety of fresh-cut melon. Int. J. Food Microbiol. 2008, 121, 313-327. [CrossRef]

14. Sipahi, R.E.; Castell-Perez, M.E.; Moreira, R.G.; Gomes, C.; Castillo, A. Improved multilayered antimicrobial alginate-based edible coating extends theshelf life of fresh-cut watermelon (Citrulluslanatus). LWT Food Sci. Tech. 2013, 51, 9-15. [CrossRef]

15. Pavlath, A.E.; Orts, W.J. Edible films: Why, what and how! In Edible Films and Coatings for Food and Otherapplications; Embuscado, M.E., Huner, K., Eds.; Springer: Berlin/Heidelberg, Germany, 2009; pp. 1-23, Chapter 1.

16. Tantawy, A.S.; Abdel-Mawgoud, A.M.R.; Zaki, M.F.; Saleh, S.A. Amelioration of salinity negative effects on two hybrids of cantaloupe by nano potassium application. Int. J. Pharm. Tech. Res. 2016, 9, 317-326.

17. Abbas, M.; Buntinx, M.; Deferme, W.; Peeters, R. (Bio)polymer/ZnO nanocomposites for packagingapplications: A review of gas barrier and mechanical properties. Nanomaterials 2019, 9, 1494. [CrossRef]

18. Monica, R.C.; Cremonini, R. Nanoparticles and higher plants. Caryologia 2009, 62, 161-165. [CrossRef]

19. Singh, A.K.; Raykar, V.S. Microwave synthesis of silver nanofluids with polyvinyl pyrolidine (PVP) and their transport properties. Colloid Polym. Sci. 2008, 286, 1667-1673. [CrossRef] 
20. Sangsuwan, J.; Rattanapanone, N.; Rachtanapun, P. Effect of chitosan/methyl cellulose films on microbial and quality characteristics of fresh-cut cantaloupe and pineapple. Postharvest Biol. Tech. 2008, 49, 403-410. [CrossRef]

21. Fujishima, A.; Rao, T.N.; Tryk, D.A. Titanium dioxide photocatalysis. J. Photochem. Photobiol. C Photochem. Rev. 2000, 1, 1-21. [CrossRef]

22. Maneerat, C.; Hayata, Y. Antifungal activity of $\mathrm{TiO}_{2}$ photocatalysisagainst Penicilliumexpansum in vitro and in fruit tests. Int. J. Food Microbiol. 2006, 107, 99-103. [CrossRef] [PubMed]

23. Chawengkijwanich, $\mathrm{C}$; Hayata, $\mathrm{H}$. Development of $\mathrm{TiO}_{2}$ powder-coated food packaging film and its ability to inactivate Escherichia coli in vitro and in actual tests. Int. J. Food Microbiol. 2008, 123, 288-292. [CrossRef]

24. Koh, P.C.; Noranizan, M.A.; Karim, R.; NurHanani, Z.A. Microbiological stability and quality of pulsed light treated cantaloupe (Cucumismelo L. reticulatus cv. Glamour) based on cut type and light fluence. J. Food Sci. Tech. 2016, 53, 1798-1810. [CrossRef] [PubMed]

25. Gómez, P.L.; Salvatori, D.M.; García-Loredo, A.; Alzamora, S.M. Pulsed light treatment of cut apple: Dose effect on color, structure, and microbiological stability. Food Bioprocess Tech. 2012, 5, 2311-2322. [CrossRef]

26. Yousuf, B.; Kumar, S.A. Flaxseed gum in combination with lemongrass essential oil as an effective edible coating for ready-to-eat pomegranate arils. Int. J. Biol. Macromol. 2017, 104, 1030-1038. [CrossRef]

27. AOAC. Official Methods of Analysis of the Association of Office Analytical Chemists, 15th ed.; Association of Official Analytical Chemists: Washington, DC, USA, 1990.

28. Yang, F.M.; Li, H.M.; LI, F.; Xin, Z.H.; Zhao, L.Y.; Zheng, Y.H.; Hu, Q.H. Effect of nano-packing on preservation quality of fresh strawberry (Fragariaananassa Duch. cv Fengxiang) during storage at $4{ }^{\circ} \mathrm{C}$. J. Food Sci. 2010, 75, C236-C240. [CrossRef]

29. Vicente, A.R.; Mar'tınez, G.A.; Chaves, A.R. Effect of heat treatment on strawberry fruit damage and oxidative metabolism during storage. Postharvest Biol. Tech. 2006, 40, 116-122. [CrossRef]

30. Munira, Z.A.; Rosnah, S.; Zaulia, O.; Russly, A.R. Effect of postharvest storage of whole fruit on physico-chemical and microbial changes of fresh-cut cantaloupe (Cucumismelo L. reticulatus cv. Glamour). Int. Food Res. J. 2013, 20, 501-508.

31. Haffez, M.M.; Ragab, M.E.; Abou El-Yazied, A.; Emam, M.S. Effect of chitosan, carboxy methyl cellulose and calcium chloride treatments on quality and storability of fresh cut Cantaloupe. Middle East J. Appl. Sci. 2016, 6, 249-268.

32. Salama, M.S.; Musafija-Jeknic, T.; Sandine, W.E.; Giovannoni, S.J. An ecology study of Lactic acid bacteria: Isolation of new strains of Lactococcusincluding Lactococcus lactis subspecies cremoris. J. Dairy Sci. 1995, 78, 1004-1017. [CrossRef]

33. Devlieghere, F.; Vermeulen, A.; Debevere, J. Chitosan: Antimicrobial activity, interactions with food components and applicability as a coating on fruit and vegetables. Food Microbiol. 2004, 21, 703-714. [CrossRef]

34. Zhang, Y.; Ma, Q.; Critzer, F.; Davidson, P.M.; Zhong, Q. Effect of alginate coatings with cinnamon bark oil and soybean oil on quality and microbiological safety of cantaloupe. Int. J. Food Microbiol. 2015, 215, 25-30. [CrossRef] [PubMed]

35. Magwaza, L.S.; Opara, U.L. Analytical methods for determination of sugars and sweetness of horticultural products-A review. Sci. Hort. 2015, 184, 179-192. [CrossRef]

36. Hernandez-Munoz, P.; Almenar, E.; Valle, V.D.; Velez, D.; Gavara, R. Effect of chitosan coating combined with postharvest calcium treatment on strawberry (Fragaria $\times$ ananassa) quality during refrigerated storage. Food Chem. 2008, 110, 428-435. [CrossRef] [PubMed]

37. Lamikanra, O.; Chen, J.C.; Banks, D.; Hunter, P.A. Biochemical andmicrobial changes during the storage of minimally processed cantaloupe. J. Agric. Food Chem. 2000, 48, 5955-5961. [CrossRef]

38. Kou, X.; He, Y.; Li, Y.; Chen, X.; Feng, Y.; Xue, Z. Effect of abscisic acid (ABA) and chitosan/nano-silica/sodium alginate composite film on the color development and quality of postharvest Chinese winter jujube (Zizyphusjujuba Mill. cv. Dongzao). Food Chem. 2019, 270, 385-394. [CrossRef]

39. Mousavizadeh, S.J.; Sedaghathoor, S. Apple and quince peroxidase activity in response to essential oils application. Afr. J. Biotech. 2011, 10, 12319-12325. [CrossRef]

40. Piscopo, A.; Zappia, A.; Princi, M.P.; De Bruno, A.; Araniti, F.; Antonio, L.; Abenavoli, M.R.; Poiana, M. Quality of shredded carrots minimally processed by different dipping solutions. J. Food Sci. Tech. 2019, 56, 2584-2593. [CrossRef] 
41. Charles, F.; Vidal, V.; Olive, F.; Filgueiras, H.; Sallanon, H. Pulsed light treatment as new method to maintain physical and nutritional quality of fresh-cut mangoes. Innov. Food Sci. Emerg. Tech. 2013, 18, $190-195$. [CrossRef]

42. Boynton, B.B.; Welt, B.A.; Sims, C.A.; Brecht, J.K.; Balaban, M.O.; Marshall, M.R. Effects of low-dose electron beam irradiation on respiration, microbiology, color, and texture of fresh-cut cantaloupe. Horttechy 2005, 15, 802-807. [CrossRef]

43. Kim, M.; Cho, A.E. The role of water molecules in stereoselectivity of glucose/galactose-binding protein. Sci. Rep. 2016, 6, 36807. [CrossRef] [PubMed]

(C) 2019 by the authors. Licensee MDPI, Basel, Switzerland. This article is an open access article distributed under the terms and conditions of the Creative Commons Attribution (CC BY) license (http://creativecommons.org/licenses/by/4.0/). 